\title{
Reference gene selection for quantitative RT-PCR normalisation in barley under low-nitrogen stress, based on RNAseq data
}

\author{
Zhiwei Chen ${ }^{\mathrm{a}, 1}$, Yingbo Li ${ }^{\mathrm{a}, 1}$, Chenghong Liu ${ }^{\mathrm{a}}$, Yifei Wang ${ }^{\mathrm{a}}$, Ting $\mathrm{He}^{\mathrm{a}}$, Guimei Guo ${ }^{\mathrm{a}}$, \\ Chunyan Fang ${ }^{a}$, Runhong Gao ${ }^{a}$, Hongwei Xu ${ }^{a}$, Longhua Zhou ${ }^{a}$, Jianhua Huang ${ }^{\mathrm{a}, * *}$, \\ Nigel G. Halford ${ }^{\mathrm{b}, * * *}$, Ruiju Lu ${ }^{\mathrm{a}, *}$ \\ a Shanghai Key Laboratory of Agricultural Genetics and Breeding, Biotechnology Research Institute, Shanghai Academy of Agricultural Sciences, Shanghai, 201106, China \\ b Plant Sciences Department, Rothamsted Research, Harpenden, Hertfordshire AL5 2JQ, United Kingdom
}

A R T I C L E I N F O

\section{Keywords:}

Barley

Reference gene

qRT-PCR

Low-nitrogen stress

Quantitative reverse transcription-polymerase chain reaction (qRTPCR) is widely used for the investigation of gene expression. In this technique, the choice of reference genes for normalisation of gene expression is crucial for the accurate measurement of target gene expression. However, the expression of some so-called housekeeping genes has been found to be less stable than previously thought, especially under stress conditions (Volkov et al., 2003). To provide better, more stable reference genes for $\mathrm{QRT}$-PCR, several software products have been developed, including geNorm (Vandesompele et al., 2002), NormFinder (Andersen et al., 2004) and BestKeeper (Pfaffl et al., 2004).

The reducing cost of next generation sequencing (NGS) means that RNAseq analysis is frequently being used as an alternative to qRT-PCR for the investigation of gene expression. RNAseq results are often validated by qRT-PCR, but RNAseq analyses have also revealed hitherto uncharacterized genes that show very stable expression under different conditions, and these genes are candidates in the search for better reference genes for qRT-PCR analyses.

The aim of the present study was to identify genes that could be used for the normalisation of qRT-PCR data in barley, using RNAseq data (NCBI accession number PRJNA400519: RNA sequencing of Hordeum vulgare $\mathrm{L}$. under low nitrogen stress). The particular interest was in genes that were stably expressed under different nitrogen conditions, including low-nitrogen stress. Transcriptomic analyses and validations by qRT-PCR have been reported previously in barley under low-nitrogen stress (Quan et al., 2016; Wei et al., 2016). However, those studies did not include any discussion of the criteria used for the selection of reference genes for the qRT-PCR analyses.

Seedlings of two barley genotypes, BI-04 and BI-45, were cultured in nutrient solution containing $114.3 \mathrm{mg} / \mathrm{L}(1.43 \mathrm{mM}) \mathrm{NH}_{4} \mathrm{NO}_{3}, 50.4 \mathrm{mg} /$ $\mathrm{L} \mathrm{NaH}_{2} \mathrm{PO}_{4} \cdot 2 \mathrm{H}_{2} \mathrm{O}, 89.3 \mathrm{mg} / \mathrm{L} \mathrm{K} \mathrm{K}_{4}, 110.8 \mathrm{mg} / \mathrm{L} \mathrm{CaCl}_{2}, 405.0 \mathrm{mg} / \mathrm{L}$ $\mathrm{MgSO}_{4}, 1.6 \mathrm{mg} / \mathrm{L} \quad \mathrm{MnSO}_{4} \cdot \mathrm{H}_{2} \mathrm{O}, 18.8 \mu \mathrm{g} / \mathrm{L} \quad \mathrm{Na}_{2} \mathrm{MoO}_{4} \cdot \mathrm{H}_{2} \mathrm{O}, 1.2 \mathrm{mg} / \mathrm{L}$ $\mathrm{H}_{3} \mathrm{BO}_{3}, 43.8 \mu \mathrm{g} / \mathrm{L} \mathrm{ZnSO}{ }_{4} \cdot 7 \mathrm{H}_{2} \mathrm{O}, 38.8 \mu \mathrm{g} / \mathrm{L} \mathrm{CuSO}_{4} \cdot 5 \mathrm{H}_{2} \mathrm{O}$, and $15.0 \mathrm{mg} / \mathrm{L}$ ironic citrate. The seedlings were grown with a $16 \mathrm{~h} / 8 \mathrm{~h}$ (light/dark) cycle, with light provided at a photon flux density at plant level equal to $300 \mu \mathrm{mol} \mathrm{m}{ }^{-2} \mathrm{~s}^{-1}$. Temperature was $20^{\circ} \mathrm{C} \pm 2{ }^{\circ} \mathrm{C}$, with $70 \%$ relative humidity. The seedlings were transferred to low nitrogen nutrient solution $(0.24 \mathrm{mM}$ ammonium nitrate) at the emergence of the fourth leaf, and shoots were harvested immediately $(0 \mathrm{~h})$ or at $1 \mathrm{~h}$ and $24 \mathrm{~h}$ after the start of the low-N treatment. There were three biological replicates for each sample. Total RNA was isolated by Trizol (InVitrogen, USA), and treated with RQ1 RNase-Free DNase (Promega, USA). cDNA was synthesised using PrimeScript II 1st strand cDNA Synthesis Kit (TaKaRa, Japan), and checked as described (Chen et al., 2013).

Three transcripts showing stable expression were selected from the

\footnotetext{
* Corresponding author.

** Corresponding author.

*** Corresponding author.

E-mail addresses: czw1900@aliyun.com (Z.Chen), liyingbo163@163.com (Y. Li), Chliu001@saas.sh.cn (C. Liu), cs1@saas.sh.cn (Y. Wang), green1216@sina.com (T. He), guo_gm@126.com (G. Guo), 18896578395@163.com (C. Fang), gaorunhong2005@163.com (R. Gao), xuhongwei_2009@126.com (H. Xu), zhou_longhua@sina.com (L. Zhou), sw1@saas.sh.cn (J. Huang), nigel.halford@rothamsted.ac.uk (N.G. Halford), luruiju62@163.com (R. Lu).

${ }^{1}$ Zhiwei Chen and Yingbo Li contributed equally to this work.
} 
Table 1

Details of the eight candidate reference genes and nucleotide sequences of primers used in the qRT-PCR analyses.

\begin{tabular}{|c|c|c|c|c|c|c|}
\hline $\begin{array}{l}\text { Candidate reference } \\
\text { genes }\end{array}$ & Accession number & Annotation & Primer nucleotide sequence $\left(5^{\prime}-3^{\prime}\right)$ & Amplicon (bp) & $\begin{array}{l}\text { PCR } \\
\text { efficiency }\end{array}$ & Origin \\
\hline UBE2 & MLOC_9934.1 & ubiquitin-conjugating enzyme E2-like & $\begin{array}{l}\text { F: TTTTTGGCCCTGATGATAGC } \\
\text { R: CCGAACTGTTGGTGGCTTAT }\end{array}$ & 95 & 1.812 & This study \\
\hline EF2 & MLOC_15661.3 & elongation factor 2-like & $\begin{array}{l}\text { F: AATCAAGGACTCCGTTGTGG } \\
\text { R: CGTCACAGACCTCAAAGCAA }\end{array}$ & 98 & 1.777 & \\
\hline$\beta$-TUB6 & MLOC_74587.1 & beta tubulin 6 & $\begin{array}{l}\text { F: TCCCGAACAATGTCAAGTCA } \\
\text { R: GTGGAGTTGCCAATGAAGGT }\end{array}$ & 82 & 1.779 & \\
\hline$A D P$ & AJ508228.2 & ADP-ribosylation factor 1-like & $\begin{array}{l}\text { F: GCTCTCCAACAACATTGCCAAC } \\
\text { R: GAGACATCCAGCATCATTCATTCC }\end{array}$ & 77 & 1.748 & Ferdous et al., 2015 \\
\hline GAPDH1 & X60343.1 & $\begin{array}{l}\text { glycolytic glyceraldehyde-3-phosphate } \\
\text { dehydrogenase }\end{array}$ & $\begin{array}{l}\text { F: GCCAAGACCCAGTAGAGC } \\
\text { R: CACATTTATTCCCATAGACAAAGG }\end{array}$ & 78 & 1.740 & \\
\hline GAPDH2 & M36650.1 & $\begin{array}{l}\text { glycolytic glyceraldehyde-3-phosphate } \\
\text { dehydrogenase }\end{array}$ & $\begin{array}{l}\text { F: AAGCATGAAGATACAGGGAGTGTG } \\
\text { R: AATTTATTCTCGGAAGAGGTTGTACA }\end{array}$ & 74 & 1.735 & Quan et al., 2016 \\
\hline$A C T$ & AY145451.1 & actin & $\begin{array}{l}\text { F: TGAGGCGCAGTCCAAGAGA } \\
\text { R: TCCATGTCATCCCAGTTGCTTA }\end{array}$ & 81 & 1.790 & Chen et al., 2013 \\
\hline CYP & AK253120.1 & Cyclophilin & $\begin{array}{l}\text { F: CCTGTCGTGTCGTCGGTCTAAA } \\
\text { R: ACGCAGATCCAGCAGCCTAAAG }\end{array}$ & 122 & 1.746 & Mangelsen et al., 2011 \\
\hline
\end{tabular}

RNAseq data. Clean reads were mapped to the barley reference genomic sequences database (http://plants.ensembl.org/info/data/ftp/index. html) and the nucleotide sequences obtained from there were used in BLAST searches of the GenBank database using the NCBI portal. These searches showed the three transcripts to derive from genes UBE2 (ubiquitin-conjugating enzyme E2-like), EF2 (elongation factor 2-like) and $\beta$-TUB6 ( $\beta$ tubulin 6 ) (Table 1 ). Five other genes were selected because they had been used in other studies (Table 1), making a total of eight candidate reference genes. PCR amplifications for nucleotide sequence analysis of these 5 candidate genes were conducted using PrimerSTART HS DNA Polymerase (TaKaRa, Japan). The reaction volume was $25 \mu \mathrm{L}$, with $5 \mu \mathrm{L}$ PrimerSTART buffer, $2 \mu \mathrm{L} 2.5 \mathrm{mM}$ dNTP, $2 \mu \mathrm{L}$ $10 \mu \mathrm{M}$ primers, $0.25 \mu \mathrm{L} 2.5 \mathrm{U} / \mu \mathrm{L}$ DNA polymerase and $1 \mu \mathrm{L}$ of synthesised cDNA. Nucleotide sequence analysis of the amplification products was carried out by Invitrogen in China.

qRT-PCR primers for UBE2, EF2 and $\beta$-TUB6 (Table 1) were designed using Primer 3 software (http://primer3.wi.mit.edu/), and the specificity of the primers was assessed by qRT-PCR melting curve analysis and gel electrophoresis of the amplified products. Each pair of primers produced a single peak in the melting curve and a single band with the expected size when analysed by gel electrophoresis (not shown). The specificity of the three pairs of newly-designed primers was further assessed by nucleotide sequence analysis of the amplified products, which confirmed the gene assignations.

Real-time PCR reactions were performed in 96-well plates using a 7500 Real-Time PCR System and PowerUp SYBR Green Master Mix (Applied Biosystems, USA). The reaction volume was $10 \mu \mathrm{L}$, with $5 \mu \mathrm{L}$ $2 \times$ PowerUp SYBR Green Master Mix, $0.6 \mu \mathrm{L} 1 \mu \mathrm{M}$ mixed primers (forward and reverse), and $1 \mu \mathrm{L} 10$-fold diluted cDNA from the original $20 \mu \mathrm{L}$ that was synthesised from the barley shoot RNA. The reaction programme for all PCR reactions was: $50^{\circ} \mathrm{C}$ for $2 \mathrm{~min}, 95^{\circ} \mathrm{C}$ for $2 \mathrm{~min}$, followed by 40 cycles of $95^{\circ} \mathrm{C}$ for $15 \mathrm{~s}$ and $60^{\circ} \mathrm{C}$ for $1 \mathrm{~min}$. Data collection was carried out at the $60^{\circ} \mathrm{C}$ step, and the melting curve analyses were conducted after cycle 40 . All Ct values were obtained at the threshold of 0.14. The average PCR efficiency obtained with each pair of primers was estimated by using the LinReg PCR programme (Ramakers et al., 2003).

Gene expression analyses of the 8 candidate reference genes in the 18 shoot samples ( 2 genotypes $\times 3$ timepoints $(0,1$ and $24 \mathrm{~h}$ in lownitrogen stress conditions) $\times 3$ biological replicates) were conducted as described by Chen et al. (2013). One-way ANOVA analysis was performed using SPSS 22 software and Ct values were compared using the $t$-test function in MS Excel 2007. The Ct values for the 8 genes over all samples showed no significant differences ( $p>0.05$ ). To analyse this further, the Ct values and PCR efficiencies were used for gene expression stability analysis by the three software products: geNorm version
3.5 (https://genorm.cmgg.be/), NormFinder version 0.953 (https:// moma.dk/normfinder-software/), and BestKeeper version 1 (http:// www.gene-quantification.de/bestkeeper.html) (Andersen et al., 2004; Pfaffl et al., 2004; Vandesompele et al., 2002).

geNorm calculates a value (M) representing average expression stability, with a lower $M$ value indicating more stability and an $M$ value above 1.5 indicating a gene with unstable expression levels. The M values for the 8 genes ranged from 0.130 to 0.293 (Table 2), showing all of the genes to be expressed stably in shoots of barley after transfer to low-nitrogen stress. However, the most stable genes were $\beta$-TUB6 (M value 0.130 ) and GAPDH2 (M value 0.130 ), while the least stable gene was CYP (M value 0.293). $\beta$-TUB6 was one of the three newly-adopted reference genes identified from RNAseq data in this study.

The NormFinder analysis calculated stability values for the 8 genes ranging from 0.064 to 0.300 (with a lower value again indicating more stability), with $A D P(0.064)$ the most stable reference gene (Table 2). The least stable gene was CYP (0.300), consistent with the geNorm analysis.

In BestKeeper, overall variation of gene expression is reflected in the standard deviation (SD) of the crossing point (Cp) values (the $\mathrm{Cp}$ is the point in the PCR reaction at which the amplification curve crosses the vertical threshold line/noise band), and a gene is considered to have unstable expression when the SD value is higher than 1 . The SDs for the 8 candidate reference genes ranged from 0.38 to 0.64 (Table 3), consistent with the other analyses. BestKeeper also combines expression data from highly correlated genes into an index, and compares candidate gene expression to this index to calculate a correlation coefficient ( $\mathrm{r}$ ), with $\mathrm{r}$ values close to 1.0 indicating the most stable genes. The $\mathrm{r}$ values for the 8 genes ranged from 0.833 to 0.960 , with $A D P(0.960)$ and GAPDH1 (0.960) the two most stable genes (Table 3), while the

Table 2

Expression stability ranking of candidate reference genes by geNorm, NormFinder and BestKeeper.

\begin{tabular}{lllllll}
\hline $\begin{array}{l}\text { Candidate } \\
\text { reference } \\
\text { gene }\end{array}$ & geNorm & \multicolumn{3}{l}{ NormFinder } & \multicolumn{2}{l}{ BestKeeper } \\
\cline { 2 - 7 } & M value & $\begin{array}{l}\text { Ranking } \\
\text { order }\end{array}$ & $\begin{array}{l}\text { Stability } \\
\text { value }\end{array}$ & $\begin{array}{l}\text { Ranking } \\
\text { order }\end{array}$ & $\begin{array}{l}\text { Stability } \\
\text { value }\end{array}$ & $\begin{array}{l}\text { Ranking } \\
\text { order }\end{array}$ \\
\hline$\beta$-TUB6 & 0.130 & 1 & 0.095 & 2 & 0.949 & 3 \\
GAPDH2 & 0.130 & 1 & 0.115 & 5 & 0.939 & 4 \\
GAPDH1 & 0.168 & 3 & 0.107 & 3 & 0.960 & 1 \\
ADP & 0.185 & 4 & 0.064 & 1 & 0.960 & 1 \\
UBE2 & 0.198 & 5 & 0.108 & 4 & 0.917 & 5 \\
$A C T$ & 0.214 & 6 & 0.149 & 6 & 0.860 & 6 \\
EF2 & 0.237 & 7 & 0.174 & 7 & 0.833 & 8 \\
CYP & 0.293 & 8 & 0.300 & 8 & 0.844 & 7 \\
\hline
\end{tabular}


Table 3

Gene expression analysis of eight candidate references genes by Best Keeper.

\begin{tabular}{|c|c|c|c|c|c|c|c|c|}
\hline Factor & UBE2 & EF2 & $\beta$-TUB6 & $A D P$ & GAPDH1 & GAPDH2 & $A C T$ & CYP \\
\hline $\mathrm{n}$ & 18 & 18 & 18 & 18 & 18 & 18 & 18 & 18 \\
\hline geo Mean [Cp] & 23.54 & 30.48 & 24.19 & 24.02 & 22.22 & 21.10 & 25.02 & 19.89 \\
\hline ar Mean $[\mathrm{Cp}]$ & 23.54 & 30.48 & 24.20 & 24.03 & 22.23 & 21.11 & 25.03 & 19.91 \\
\hline $\min [\mathrm{Cp}]$ & 22.90 & 29.63 & 22.93 & 23.11 & 20.93 & 19.70 & 24.48 & 18.50 \\
\hline $\max [\mathrm{Cp}]$ & 24.57 & 31.27 & 25.20 & 25.19 & 23.45 & 22.06 & 25.88 & 21.69 \\
\hline std $\operatorname{dev}[ \pm \mathrm{Cp}]$ & 0.38 & 0.45 & 0.40 & 0.41 & 0.43 & 0.44 & 0.42 & 0.64 \\
\hline $\mathrm{CV}[\% \mathrm{Cp}]$ & 1.62 & 1.48 & 1.65 & 1.72 & 1.95 & 2.09 & 1.67 & 3.19 \\
\hline $\mathrm{r}$ & 0.917 & 0.833 & 0.949 & 0.960 & 0.960 & 0.939 & 0.860 & 0.844 \\
\hline p-value & 0.001 & 0.001 & 0.001 & 0.001 & 0.001 & 0.001 & 0.001 & 0.001 \\
\hline
\end{tabular}

least stable gene was EF2 (0.833).

The geNorm software was also used for determination of the optimal number of reference genes, by calculating the pairwise variation $V_{n} / V_{n+1}$ between two sequential normalisation factors, $\mathrm{NF}_{n}$ and $\mathrm{NF}_{\mathrm{n}+1}$. This analysis determines a number (n) of reference genes that are sufficient for the normalisation, with a $V_{n} / V_{n+1}$ value below a threshold of 0.15 . In this study, $\mathrm{V}_{2 / 3}$ for $\beta$-TUB6 (0.130) and GAPDH2 (0.130) was 0.059 , indicating that these two reference genes were sufficient for qRT-PCR normalisation (Table 3).

In conclusion, the study combined a suite of reference gene selection software and the analysis of RNAseq data to identify and analyse the stability of selected reference genes in barley shoots as they were transferred to conditions of low-nitrogen stress. ADP, $\beta$-TUB6 and $G A P D H 1$ were the three most stable reference genes identified by both NormFinder and Bestkeeper, while geNorm identified the three most stable reference genes as $\beta$-TUB6, GAPDH2 and GAPDH1. $\beta$-TUB6 and $G A P D H 1$ were therefore in the top three genes identified by all three software products.

The optimal number of reference genes to be used was calculated as two; an important result given that many published studies have used only a single reference gene, including two studies related to low-nitrogen stress in barley (Quan et al., 2016; Wei et al., 2016). We recommend the use of $\beta$-TUB6 in combination with GAPDH2 for qRT-PCR normalisation in barley under low-nitrogen stress.

The genes that were identified as potential reference genes from the RNAseq data were shown to be relatively stable in the qRT-PCR results, confirming that the approach of selecting reference genes based on a combination of RNAseq and qRT-PCR data was a valid one.

\section{Acknowledgements}

The research was supported by the Shanghai Natural Science Foundation of China (17ZR1425300), the Young Talent Development Plan of Shanghai Agriculture Committee of China [Grant No. 2017(127)] and China Agriculture Research System (CARS-05-01A-02). We also thank Mr. Y. Shen in Heilongjiang Bayi Agricultural University for his suggestions on using the different software. NGH is supported at Rothamsted Research by the UK's Biotechnology and Biological
Sciences Research Council through the Designing Future Wheat programme (BBS/E/C/00010220).

\section{Appendix A. Supplementary data}

Supplementary data related to this article can be found at http://dx. doi.org/10.1016/j.jcs.2018.06.014.

\section{References}

Andersen, C.L., Jensen, J.L., Ørntoft, T.F., 2004. Normalisation of real-time quantitative reverse transcription-PCR data: a model-based variance estimation approach to identify genes suited for normalisation applied to bladder and colon cancer data sets. Canc. Res. 64, 5245-5250.

Chen, Z., Muttucumaru, N., Powers, S.J., Halford, N.G., 2013. Expression analysis of abscisic acid (ABA) and metabolic signalling factors in developing endosperm and embryo of barley. J. Cereal. Sci. 58, 255-262.

Ferdous, J., Li, Y., Reid, N., Langridge, P., Shi, B.J., Tricker, P.J., 2015. Identification of reference genes for quantitative expression analysis of microRNAs and mRNAs in barley under various stress conditions. PLoS One 10, e0118503.

Mangelsen, E., Kilian, J., Herter, K., Jansson, C., Wanke, D., Sundberg, E., 2011. Transcriptome analysis of high-temperature stress in developing barley caryopses: early stress responses and effects on storage compound biosynthesis. Mol. Plant 4 97-115.

Pfaffl, M.W., Tichopad, A., Prgomet, C., Neuvians, T.P., 2004. Determination of stable housekeeping genes, differentially regulated target genes and sample integrity: BestKeeper-Excel-based tool using pair-wise correlations. Biotechnol. Lett. 26, 509-515.

Quan, X., Zeng, J., Ye, L., Chen, G., Han, Z., Shah, J.M., Zhang, G., 2016. Transcriptome profiling analysis for two Tibetan wild barley genotypes in responses to low nitrogen. BMC Plant Biol. 16, 30.

Ramakers, C., Ruijter, J.M., Deprez, R.H., Moorman, A.F., 2003. Assumption-free analysis of quantitative real-time polymerase chain reaction (PCR) data. Neurosci. Lett. 339, 62-66.

Vandesompele, J., De Preter, K., Pattyn, F., Poppe, B., Van Roy, N., De Paepe, A., Speleman, F., 2002. Accurate normalization of real-time quantitative RT-PCR data by geometric averaging of multiple internal control genes. Genome Biol. 3 research0034.1-research0034.11.

Volkov, R.A., Panchuk, I.I., Schöffl, F., 2003. Heat-stress-dependency and developmental modulation of gene expression: the potential of house-keeping genes as internal standards in mRNA expression profiling using real-time RT-PCR. J. Exp. Bot. 54, 2343-2349.

Wei, Z., Zeng, X., Qin, C., Wang, Y., Bai, L., Xu, Q., Yuan, H., Tang, Y., Nyima, T., 2016. Comparative transcriptome analysis revealed genes commonly responsive to varied nitrate stress in leaves of Tibetan hulless barley. Front. Plant Sci. 7, 1067. 